The object of the study was the introduced species of the genus Clematis. Analysis of bioecomorphs of introducers, and the biometric indicators of morphological observations of plants. The word «Clematis» came into Latin terminology from the ancient Greek word «Clema» meaning tendril. Dioscorides first mentions this term when describing twisted plants. The generic name was first used by K. Linnaeus in «Species plantarum». Lominos have been cultivated in European gardens for over 400 years. Species of the genus Clematis are found in 28 of the 34 floristic regions around the globe. The life forms of plants are very diverse (from semi-shrubs to woody vines). These plants retain their decorative qualities until late autumn and form, especially when planted on the lawn, bright spots of various colors, and, therefore, have a decorative effect, decorative leaves and flowers, and even seeds, during the growth season give rapid shoot growth. In the Kremenets region, this culture is little known, as the range of species, as well as their bioecological features in different areas of introduction are poorly studied. Clematis has long been used in ornamental horticulture, while in the landscaping of cities Clematis is not used and is most common in the gardens of amateur gardeners. The growing season during the introduction test is 187-238 days. The studied species bloom for up to 85 days and some species have repeated flowering. The beginning and duration of the phases of growth and flowering differ significantly for different species and varieties of Clematis and depend on biological characteristics, geographical origin, as well as agricultural techniques. It is usually propagated by seeds and vegetatively - by layering, dividing the bush, cuttings or grafting, seeds are often propagated species with small flowers; their seeds germinate fast in spring. For species with large seeds, the germination period is extended by 80 (500) days.

Key words: Clematis, Kremenets Botanical Garden, introduction, section, clematis, cultivation, vegetation, plant.

Надійшла 15.10.2020.

УДК 582.732: $581.52(477)$

doi: $10.25128 / 2078-2357.20 .3-4.2$

${ }^{1}$ А. О. ЗАГОРУЛЬКО, ${ }^{2,3}$ I. І. КОРШИКОВ

${ }^{1}$ Херсонський державний університет

вул. Університетська, 27, Херсон, 73000

${ }^{2}$ Криворізький ботанічний сад НАН України

вул. Маршака, 50, Кривий Ріг, 50089

${ }^{3}$ Донецький ботанічний сад НАН України

вул. Маршака, 16А, Кривий Ріг, 50089

e-mail: alenazagorulko9@gmail.com

\title{
ПЛАТАН КЛЕНОЛИСТИЙ (PLATANUS ACERIFOLIA WILLD.) В УМОВАХ МІСТ СТЕПОВОЇ ЗОНИ УКРӒ̈НИ
}

Здійснено порівняльний аналіз життєвого стану та біометричних параметрів Platanus acerifolia Willd. у насадженнях двох міст степової зони України. Виявлено, що P. acerifolia широко використовується в озелененні м. Херсон, тоді як у Кривому Розі трапляється рідко. Вік дерев у Херсоні становить 38-60р. Життєвий стан оцінено як високий та близький до високого - 77,8$96,3 \%$. Старші за віком дерева відзначаються найбільшою висотою - 18,4-21,5 м та максимальним діаметром стовбура 80,1-99,4 см. У рослин всіх насаджень у Херсоні відмічена наявність сухих гілок, що становить 6,3-28,7 \%. У Кривому Розі зростають дерева віком 28-42 років. У різних насадженнях $P$. acerifolia кількість сухих гілок варіює в межах 0,3-44,5 \%, а життєвий стан - від 55,5 до 100 \% залежно від місця зростання. Висота дерев P. acerifolia складає 6,2-20,3 м, а діаметр стовбура 12,2-68,7 см. Встановлено, що відмінності життєвого стану та морфометричних показників дерев в насадженнях цих міст залежать від віку дерев, щільності їх посадки, освітленості та інших умов зростання, у першу чергу від затишності 
території. Дерева в Кривому Розі більш суттєво, ніж у Херсоні, пошкоджені холодними вітрами. Відмічено, що Platanus acerifolia $є$ перспективним видом для більш широкого використання в озелененні міст Причорномор'я та населених пунктів Правобережного Степу, однак в останніх для успішного зростання потребують вибору експозиційних місць. Це, у першу чергу, повинні бути місця, захищені від впливу холодних вітрів взимку і суховіїв у весняно-літній періоди.

Ключові слова: Platanus acerifolia Willd., морфометричні параметри, життєвий стан, Херсон, Кривий Piz.

Сучасні міста степової зони України потребують часткової заміни та поповнення асортименту деревних рослин $з$ двох головних причин: більшість видів, особливо роду Populus L., досягли критичного віку, а також досить суттєво змінились кліматичні умови в зв'язку з глобальним потеплінням. Значно збільшилась тривалість посух, які можуть продовжуватись 2-3 місяці 3 середини літа до жовтня місяця. Також у цей період зросла кількість днів 3 підвищеною температурою $30{ }^{\circ} \mathrm{C}$ і більше. Для степових міст важливим є поповнення асортименту стійкими декоративними видами, що швидко ростуть і формують об'ємну крону. Такі рослини за рахунок затінення великих площ створюють більш комфортні умови для проживання людей у степових містах. До таких перспективних видів належить платан кленолистий (Platanus acerifolia Willd.), який спорадично в деяких містах почали висаджувати в післявоєнні часи. В озелененні населених пунктів Причорномор'я і Приазов'я цей вид активно застосовують 3 7080-тих років XX століття та переміщують в північні райони Правобережного Степу і Лісостепу України [3].

P. acerifolia - це гібрид, який виник від схрещування платана східного (P. orientalis L.) i платана західного (P. occidentalis L.) в Англії у середині XVII століття. В Європі він дуже поширений у культурі [10]. Інтродукція платанів починалась у Криму, куди вперше у 1786 році було завезено насіння одного з видів. У Нікітському ботанічному саду колекція платанів була зібрана в 1814-1828 роках. 3 того часу в Криму культивували платан, який вирощували 3 місцевого насіння. Вихід сіянців у розсаднику Нікітського ботанічного саду становив до 200 тис. в рік. Домінує в насадженнях Криму P. acerifolia, у той час як P. orientalis трапляється рідко, P. occidentalis - в одиничних екземплярах [9].

У Криворізькому ботанічному саду НАН України (КБС) уперше два саджанці P. acerifolia були завезені з Донецького ботанічного саду у 1984 році, а вже з 1990 року висаджували молоді рослини місцевої репродукції [8]. В Одесі цей вид культивується уже понад 100 років, у Новій Каховці використовують в озелененні більше 70 років. Старі дерева P. acerifolia зростають в насадженнях Херсона, Голої Пристані, на Закарпатті (Ужгород, Мукачеве та ін.). Присутній платан і в насадженнях населених міст Сумської та Харківської областей [10]. У старих парках Буковини зростають понад 30 дерев цього виду. Найстаріше дерево в Україні росте у Маківському парку, вік якого становить близько 150-200 років [6, 7].

Життєздатність $P$. acerifolia в умовах степу різна. Так, в умовах дендрарію КБС цей вид відзначився високою посухостійкістю та середньою зимостійкістю i низькою пило- i газостійкістю [8]. Наявність об' ємної крони і великої маси листя дозволяє одному розвиненому дереву P. acerifolia осаджувати за вегетаційний період 3,6-13,5 кг пилу із повітря в таких містах як Дніпропетровськ, Донецьк, Бердянськ [5]. Біологічні особливості цього перспективного інтродуценту мало досліджені в умовах різних за соціально-економічними проблемами в містах, що відрізняються за природно-кліматичними умовами.

Мета роботи - порівняльна характеристика життєвого стану та біометричних характеристик P. acerifolia в насадженнях міст Херсону та Кривого Рогу.

\section{Матеріал і методи досліджень}

Місто Херсон, у якому в озелененні уже 40-50 років досить широко використовують P. acerifolia, знаходиться в зоні сухого степу. Кліматичні показники тут такі: сумарна річна кількість опадів коливається в межах 350-470 мм/рік, середньорічна температура $-+10{ }^{0} \mathrm{C}$ [1]. Стан рослин вивчали і у насадженнях великого промислового міста - Кривого Рогу, що 
географічно знаходиться більше як за 200 км від Херсону. Середня річна температура у місті $+8,5^{\circ} \mathrm{C}$, а сумарна кількість опадів - 400-450 мм/рік [4].

Проводили дослідження морфометричних характеристик та життєвого стану дерев P. acerifolia, а також їх статистичну обробку.

\section{Результати досліджень та їх обговорення}

У Херсоні $P$. acerifolia є одною із головних деревних порід, у центральній і східній частині міста його частка в зелених насадженнях становить близько $35 \%$. У північному і західному районах міста частка цього виду в зелених насадженнях також висока і становить відповідно $25 \%$, і $20 \%$. У південному районі міста вона складає $5 \%$. Загальна доля P. acerifolia в Херсоні становить близько $24 \%$. У місті є багато вулиць, які озеленені тільки цим видом. Досить часто P. acerifolia насаджують біля адмінбудівель, шкіл, лікарень, зростає також у парках, скверах та в дворах багатоповерхових будинків.

Морфометричні показники дерев в насадженнях Херсону залежать від віку, щільності посадки, освітленості та інших умов зростання, у першу чергу затишності, наскільки будівлі захищають рослини від суховіїв та холодних вітрів взимку та навесні. Найбільш високими виявились 60-річні дерева - 20-21 м, хоча і 45-річні на Бериславському шосе мали висоту 20 м (табл. 1).

Таблиия 1

Показники життєздатності Platanus accrifolia Willd. у насадженнях м. Херсон, 2020 р.

\begin{tabular}{|c|c|c|c|c|c|c|c|c|c|}
\hline 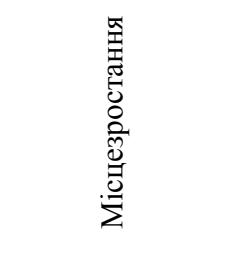 & 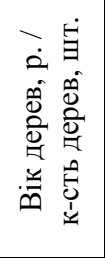 & 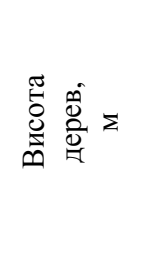 & 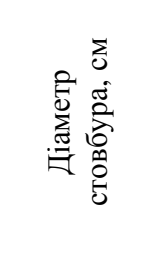 & 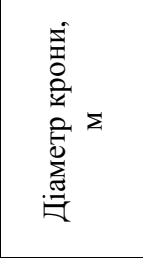 & 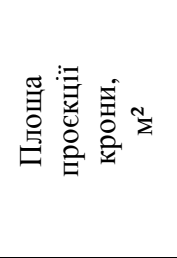 & 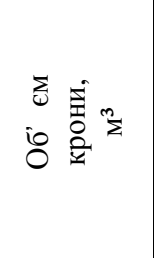 & 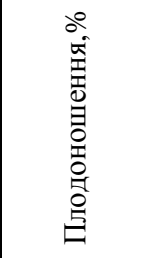 & 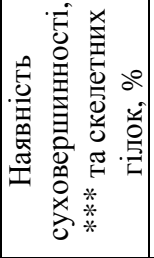 & 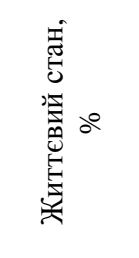 \\
\hline \multicolumn{10}{|c|}{ Східна частина міста } \\
\hline Вул. Кулика & $50 / 17$ & $15,9 \pm 0,72$ & $55,5 \pm 5,40$ & $11,2 \pm 1,03$ & $112,4 \pm 19,11$ & $\begin{array}{l}561,9 \pm \\
124,58 \\
\end{array}$ & $89,4 \pm 2,86$ & $6,5 \pm 3,17$ & $94,7 \pm 2,73$ \\
\hline $\begin{array}{c}\text { Бериславське } \\
\text { шосе }\end{array}$ & $45 / 18$ & $20,0 \pm 1,29$ & $68,5 \pm 4,02$ & $11,8 \pm 0,99$ & $122,4 \pm 22,02$ & $\begin{array}{l}754,6 \pm \\
138,06\end{array}$ & $39,7 \pm 7,76$ & $18,2 \pm 2,02$ & $84,1 \pm 2,34$ \\
\hline $\begin{array}{c}\text { Вул. } \\
\text { Перекопська }\end{array}$ & $42 / 14$ & $13,2 \pm 0,93$ & $55,5 \pm 3,62$ & $11,1 \pm 0,98$ & $100,2 \pm 15,09$ & $\begin{array}{c}398,5 \pm \\
81,74\end{array}$ & $73,1 \pm 4,33$ & $28,7 \pm 5,74$ & $78,1 \pm 5,10$ \\
\hline $\begin{array}{c}\text { Вул. } \\
\text { Університетська }\end{array}$ & $50 / 11$ & $18,5 \pm 1,94$ & $63,5 \pm 4,95$ & $8,9 \pm 1,17$ & $98,8 \pm 31,43$ & $\begin{array}{l}612,0 \pm \\
225,07\end{array}$ & $46,0 \pm 7,02$ & $19,5 \pm 3,45$ & $80,0 \pm 5,73$ \\
\hline \multicolumn{10}{|c|}{ Центральна частина міста } \\
\hline Школа № 13 & $50 / 8$ & $15,8 \pm 0,92$ & $73,6 \pm 4,33$ & $16,6 \pm 0,65$ & $217,7 \pm 18,30$ & $\begin{array}{l}892,9 \pm \\
146,54\end{array}$ & $88,8 \pm 0,82$ & $16,3 \pm 0,82$ & $88,8 \pm 2,27$ \\
\hline Пл. Свободи & $60 / 20$ & $18,4 \pm 0,26$ & $80,1 \pm 4,13$ & $11,4 \pm 0,50$ & $104,8 \pm 8,97$ & $\begin{array}{c}538,4 \pm 51 \\
19\end{array}$ & $78,5 \pm 6,24$ & $15,8 \pm 1,37$ & $88,8 \pm 1,25$ \\
\hline $\begin{array}{c}\text { Вул. } \\
\text { Маяковського }\end{array}$ & $60 / 10$ & $20,0 \pm 0,52$ & $81,4 \pm 4,86$ & $11,9 \pm 0,98$ & $118,0 \pm 17,69$ & $\begin{array}{l}688,6 \pm \\
118,12 \\
\end{array}$ & $55,5 \pm 9,50$ & $19,0 \pm 1,45$ & $81,0 \pm 1,45$ \\
\hline \multicolumn{10}{|c|}{ Північна частина міста } \\
\hline $\begin{array}{c}\text { Миколаївське } \\
\text { шосе }\end{array}$ & $50 / 24$ & $11,4 \pm 0,91$ & $51,0 \pm 4,11$ & $10,1 \pm 0,92$ & $89,8 \pm 17,69$ & $\begin{array}{l}359,6 \pm \\
105,20\end{array}$ & $60,0 \pm 4,17$ & $22,4 \pm 2,87$ & $77,8 \pm 2,92$ \\
\hline \multicolumn{10}{|c|}{ Західна частина міста } \\
\hline $\begin{array}{c}\text { Шуменський } \\
\text { мкрн. }\end{array}$ & $38 / 10$ & $13,2 \pm 0,85$ & $38,5 \pm 3,53$ & $10,4 \pm 1,05$ & $92,7 \pm 18,65$ & $\begin{array}{l}356,7 \pm \\
101,48 \\
\end{array}$ & $31,0 \pm 9,71$ & $21,5 \pm 4,54$ & $78,4 \pm 4,49$ \\
\hline \multicolumn{10}{|c|}{ Південна частина міста } \\
\hline Вул. Театральна & $50 / 10$ & $16,1 \pm 0,77$ & $62,5 \pm 4,88$ & $12,6 \pm 0,76$ & $127,7 \pm 15,39$ & $\begin{array}{c}601,1 \pm 100 \\
, 23\end{array}$ & $48,5 \pm 6,33$ & $9,2 \pm 1,61$ & $92,4 \pm 1,28$ \\
\hline \multicolumn{10}{|c|}{ Окремі екземпляри по всіх районах міста } \\
\hline Солітери & $60 / 4$ & $21,5 \pm 2,53$ & $99,4 \pm 11,14$ & $17,6 \pm 2,54$ & $259,1 \pm 25,81$ & $\begin{array}{c}1884,7 \pm \\
77,29 \\
\end{array}$ & $78,8 \pm 1,25$ & $6,3 \pm 1,25$ & $96,3 \pm 1,25$ \\
\hline
\end{tabular}


Старші за віком відзначались максимальним діаметром стовбура - 80,1-99,4 см. У 42-50річних рослин цей показник змінювався в межах 51-73,6 см, а найменшим був у 38-річних дерев $-38,5$ см. У дерев 8 із 10 насаджень діаметр крони був досить близьким - 10,1-11,9 м, тільки рослини в шкільному дворі мали більш габітусну крону $\mathrm{D}=16,6$ м, серед солітерів середнє значення - 17,6 м, а на вулиці Університетська крона майже в 2 рази менша - 8,9 м.

У Херсоні площа проєкції крони найбільша у дерев шкільного насадження $\left(217,7 \mathrm{~m}^{2}\right)$ та у солітерів $\left(259,1 \mathrm{~m}^{2}\right)$. У п’яти вуличних насаджень цей показник становить $104,8-127,7 \mathrm{~m}^{2}$, у чотирьох - 89,8-100,2 м². Максимальний об'єм крони - 1884,7 м³ мали рослини, що зростали окремо як солітери, а на подвір'ї школи цей показник 892,9 м³ $^{3}$.е у рослин чотирьох насаджень також був значний $\left(601,1-754,6\right.$ м $\left.^{3}\right)$ об' єм крони, середній $\left(538,4-561,9\right.$ м $\left.^{3}\right)$ - у двох вуличних посадках і найменший $\left(356,7-398,5 \mathrm{~m}^{3}\right)-$ у трьох алейних посадках. У дев'яти насаджень рівень плодоношення дерев був середнім (46,0-60,0 \%) або високим (73,3-89,4 \%), а ще у двох - низьким (31,0-39,7 \%). У рослин всіх насаджень відмічено наявність сухих гілок, максимальна $(28,7 \%)$-на вул. Перекопська, а мінімальна $(6,3-6,5 \%)$ - у солітерів та на вулиці Кулика. У рослин восьми насаджень життєвий стан був високим - 80,0-96,3 \% і ще у трьох близьким до цього - 77,8-78,4 \%. Наявність сухих гілок пов'язана 3 тим, що P. acerifolia як теплолюбний вид зазнає пошкоджень, коли в період початку вегетації наступають заморозки. Взимку у рослин, що ростуть у незатишних місцях, пошкоджуються однорічні пагони по периферії крони дерев. У цілому, переважна більшість насаджень P. acerifolia зберігають високу декоративність і реально впливають на мікрокліматичні умови влітку в місцях зростання. Найкращий стан дерев відмічений у центральній і східній частинах Херсону. У цих районах достатня кількість будівель, що створює більш затишні умови зростання. У насадженнях уздовж шосе життєвий стан дерев неоднорідний, у місцях, де вони захищені будівлями, він високий. У дерев на вільних просторах шосе відмічена суховерхість та значна кількість сухих гілок у кроні, що $є$ наслідком впливу суховіїв влітку і холодних вітрів взимку.

У Кривому Розі насадження P. acerifolia трапляються в одному місці - у мікрорайоні Ювілейний. Тут дерева зростають трьома групами у дворі дев'ятиповерхового будинку, який має форму букви «П». Тобто дерева $з$ трьох сторін захищені від холодних вітрів взимку та суховіїв у весняно-літній період. Усього в цьому дворі зростає 13 дерев віком 42 роки (табл. 2), висота яких варіює в межах 13,3-20,3 м, діаметр стовбура 38,3-68,7 см, діаметр крони 13,018,1 м, площа крони 124,7-259,0 м², а тї об’єм 490,8-1561,8 м³. Інші три розвинені дерева, які мало пошкоджені, зростають у шкільному дворі і відносяться до найбільш розвинених у Кривому Розі. У кроні цих дерев дуже мало сухих гілок. За морфометричними показниками рослини ботанічного саду, як правило, поступаються деревам прибудинкової території, особливо ті, що зростають на відкритих для вітрів ділянках дендрарію. Тому у цих дерев суттєво збільшується кількість сухих гілок у кроні, які наявні навіть у їх верхівках $-28,0-44,5$ $\%$. Відповідно життєвий стан за 100-бальною шкалою в рослин дендрарію становив 55,5-72,0 $\%$, а у дерев прибудинкової території та школи - 96,5-100 \%. Рослини ботанічного саду за плодоношенням значно поступаються деревам з міського насадження. Дерева, що зростають у старих парках Буковини, вік яких 115-120 років, досягають висоти до 29 м, а діаметр стовбура $-1,35$ м [2].

Ритміка вегетації P. acerifolia відповідає природно-кліматичним умовам Криворіжжя, а тривалість вегетаційного періоду становить 205-215 днів.

В умовах інтродукційного ареалу в Правобережному Лісостепу України репродуктивна зрілість P. acerifolia настає у 10-20-річному віці, одне дерево з 23-балами плодоношення може забезпечити 4-5 кг повнозернистого насіння. Розмножувати платан можна як насінням, так і живцями. Обов' язковою умовою вирощування сіянців $є$ підтримання високої вологості грунту шляхом щоденних поливів. На постійне місце необхідно висаджувати 3-4-річні сіянці і саджанці, краще в пізньоосінні строки. P. acerifolia добре росте на свіжих, вологих, сирих і відносно багатих грунтах з $\mathrm{pH} 6,5-8,0$ [3]. 
Показники життєздатності Platanus acerifolia Willd у насадженнях м. Кривий Ріг, 2017 p.

\begin{tabular}{|c|c|c|c|c|c|c|c|c|c|}
\hline 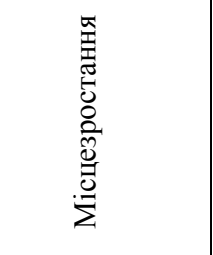 & 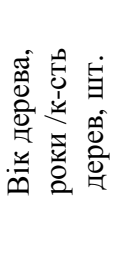 & 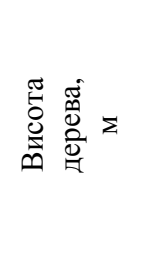 & 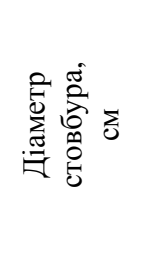 & 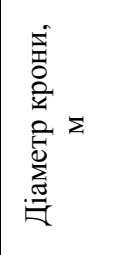 & 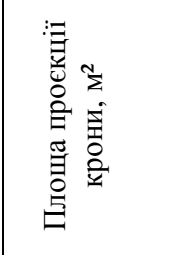 & 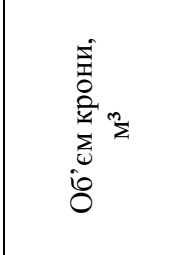 & 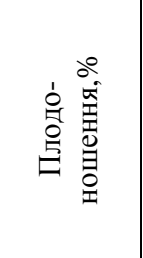 & 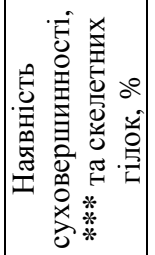 & 恖壱 \\
\hline $\begin{array}{c}\text { Дендрарій } \\
\text { КБС: } \\
\text { мододі } \\
\text { насадження }\end{array}$ & $28 / 10$ & $6,2 \pm 0,4$ & $12,2 \pm 1,3$ & $2,4 \pm 0,3$ & $4,5 \pm 1,1$ & $10,3 \pm 2,7$ & $3,0 \pm 3,0$ & $\begin{array}{c}* * \\
44,5 \pm 4,6\end{array}$ & $55,5 \pm 4,6$ \\
\hline $\begin{array}{c}\text { Дендрарій } \\
\text { КБС: } \\
\text { середньовікові } \\
\text { насадження }\end{array}$ & $30 / 12$ & $10,9 \pm 0,5$ & $19,3 \pm 1,6$ & $3,8 \pm 0,3$ & $12,5 \pm 1,5$ & $44,8 \pm 6,6$ & $1,0 \pm 0,8$ & $\begin{array}{c}* \\
37,5 \pm 3,0\end{array}$ & $62,5 \pm 3,0$ \\
\hline $\begin{array}{c}\text { Дендрарій } \\
\text { КБС: } \\
\text { найбільш } \\
\text { вікові } \\
\text { насадження }\end{array}$ & $37 / 2$ & $18,5 \pm 2,5$ & $50,5 \pm 9,5$ & $13,6 \pm 0,7$ & $144,5 \pm 14,9$ & $826,0 \pm 199,5$ & $35,0 \pm 5,0$ & $28,0 \pm 2,0$ & $72,0 \pm 2,0$ \\
\hline $\begin{array}{c}\text { Мікрорайон } \\
\text { Ювілейний: } \\
\text { I група дерев } \\
\end{array}$ & $42 / 6$ & $20,3 \pm 1,3$ & $68,7 \pm 4,0$ & $18,1 \pm 0,8$ & $259,0 \pm 21,4$ & $1561,8 \pm 199,1$ & $80,0 \pm 7,3$ & $0,3 \pm 0,2$ & $99,7 \pm 0,2$ \\
\hline $\begin{array}{c}\text { Мікрорайон } \\
\text { Ювілейний: } \\
\text { II група дерев }\end{array}$ & $42 / 4$ & $13,3 \pm 0,5$ & $38,3 \pm 6,0$ & $13,0 \pm 1,1$ & $135,7 \pm 23,4$ & $516,2 \pm 95,9$ & $95,0 \pm 5,0$ & $3,5 \pm 2,2$ & $96,5 \pm 2,2$ \\
\hline $\begin{array}{c}\text { Мікрорайон } \\
\text { Ювілейний: } \\
\text { III група дерев }\end{array}$ & $42 / 3$ & $14,0 \pm 0,6$ & $54,3 \pm 2,6$ & $15,7 \pm 1,0$ & $124,7 \pm 25,2$ & $490,8 \pm 118,7$ & $33,3 \pm 17$ & 0 & 100 \\
\hline $\begin{array}{c}\text { Подвір'я } \\
\text { ліцею }\end{array}$ & $35 / 3$ & $15,0 \pm 0,58$ & $63,4 \pm 3,68$ & $16,2 \pm 1,91$ & $211,0 \pm 51,62$ & $911,9 \pm 170,94$ & $35,5 \pm 9,11$ & 0 & 100 \\
\hline
\end{tabular}

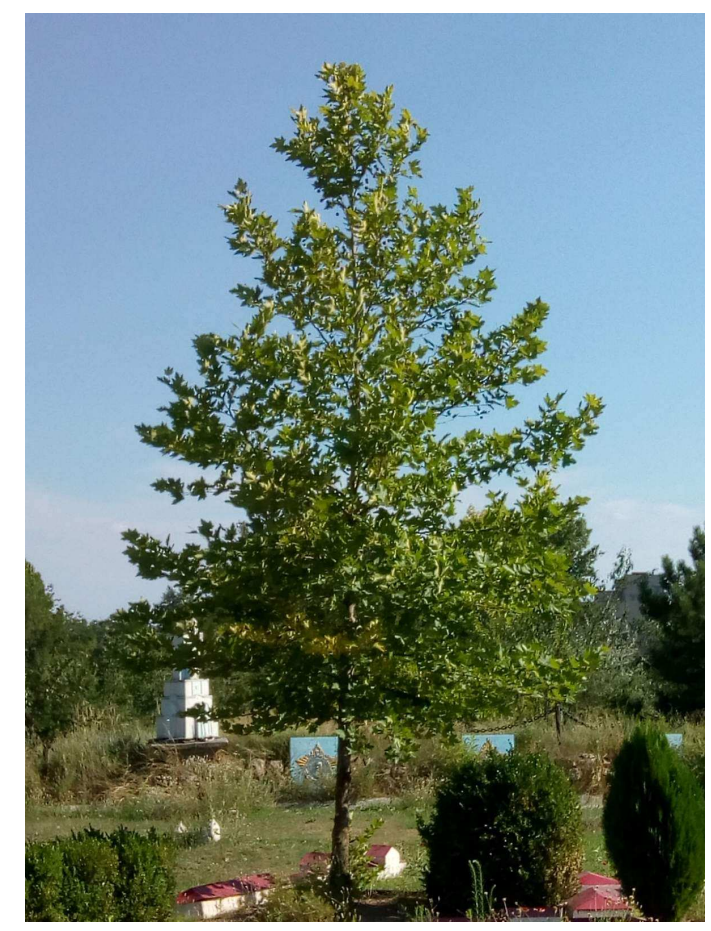

Рис. 1. Platanus acerifolia Willd. самосівного походження у м. Херсон 
Життєва форма P. acerifolia в насадженнях Херсону і Кривого Рогу - практично скрізь одностовбурове дерево. Цей вид в умовах Херсону починає натуралізуватись. У ході обстежень виявлено декілька рослин самосівного походження (рис. 1). Відмічено також відновлення рослин 3 припневої порості при спилі стовбура рослин в Херсоні. Листковий апарат P. acerifolia у ході вегетації практично не пошкоджується хворобами та шкідниками і на листках не утворюється слизовий наліт, як, наприклад, в окремих видів роду Populus L.

Отже, порівняльні дослідження насаджень $P$. acerifolia у м. Херсон і м. Кривий Ріг свідчать, що у південному місті цей вид $є$ однією із головних порід в озелененні і починається процес його натуралізації, а в промисловому, більш північному місті Кривий Ріг, він $\epsilon$ рідкісним видом. Хоча в окремих місцях цей вид зростає на продувних для вітрів територіях, однак його життєвий стан низький, а відповідно і низька декоративність. У вуличних насадженнях Кривого Рогу P. acerifolia використовувати неможливо, хоча вид придатний для озеленення тільки затишних місць, де вітрове навантаження мінімальне.

\section{Висновки}

Отже, Platanus acerifolia є перспективним видом для більш широкого використання в озелененні міст Причорномор'я та населених пунктів Правобережного Степу, однак в останньому випадку для успішного зростання потребує вибору експозиційних місць. Це, у першу чергу, повинні бути місця, захищені від впливу холодних вітрів взимку і суховіїв у весняно-літній періоди. У Кривому Розі в зимовий період у рослин відкритих територій можуть зазнавати пошкодження багато однорічних пагонів у кроні і це суттєво знижує естетичне візуальне сприйняття дерев. Значної шкоди рослинам можуть завдавати пізньовесняні заморозки. У сприятливих умовах дерева добре ростуть і розвиваються, а на відкритих територіях втрачають декоративність внаслідок утворення значної кількості сухих гілок у кроні.

1. Гамаюнов В. Е., Кухтеева К. М., Сидоренко А. И. Природные условия и почвенный покров Херсонской области: методические рекомендации для студентов агрономического и гидромелиоративного факультетов. Херсон, 1995. 45 с.

2. Грабовий В. М. Платан (Platanus L.) у Правобережному Лісостепу України / за ред. чл.-кор. НАН України І. С. Косенка. Умань : УВПП, 2007. 218 с.

3. Грабовий В. М. Перспективи використання видів роду Platanus L. у зеленому будівництві. Інтродукиія рослин. 2000. № 1. С. 72-74.

4. Екологічний паспорт міста Кривого Рогу. Кривий Ріг, 2017. 56 с.

5. Задорожная Д. В. Пылеулавливающая способность растений Platanus acerifolia (Aiton) Willd. в городских насаждениях. Інтродукція рослин. 2014. № 3. С. 74-79.

6. Липа О. Л. Платан на Україні. Наук. зап. Київ. держ. ун-ту. 1957. Т. 16. С. 152-161.

7. Термена Б. К. Платан кленолистний на Україні. Інтродукиія та акліматизація рослин в Украӥні. 1971. Вип. 5. С. 43-49.

8. Федоровский В. Д., Мазур А. Е. Древесные растения Криворожского ботанического сада. Днепропетровск : Прогресс, 2007. 256 с.

9. Шкарпет О.Д. Интродукция платанов Крыму. Бюллетень государственного Никитского ботанического сада. 1987. Вып. 63. С. 18-21.

10. Щепотьев Ф. Л., Павленко Ф.А. Разведение быстрорастущих древесных пород. М. : Лесная промышленность, 1975. 232 с.

\section{References}

1. Gamayunov V. E., Kukhteeva K. M., Sidorenko A. I. Natural conditions and soil cover of Kherson region. Methodical recommendations for students of agronomic and hydro-ameliorative faculties. Kherson, 1995. 45 s. [in Russian]

2. Hrabovyi V. M. Planetree (Platanus L.) in the Right-Bank Forest-Steppe of Ukraine / Za red. chl.-kor. NAN Ukrainy I. S. Kosenka. Uman : UVPP. 2007. 218 s. [in Ukrainian]

3. Hrabovyi V. M. Prospects for the use of species of the genus Platanus L. in green building. Introduktsiya roslyn. 2000. № 1. S. 72-74. [in Ukrainian]

4. Ecological passport of the city of Kryvyi Rih. Kryvyi Rih, 2017. 56 s. [in Ukrainian] 
5. Zadorozhnaya D. V. Dust-collecting ability of Platanus acerifolia (Aiton) Willd. in urban plantations. Introduktsiya roslin. 2014. № 3. S. 74-79. [in Russian]

6. Lypa O. L. Planetree in Ukraine. Nauk. zap. Kyiv. derzh. un-tu. 1957. T. 16. S. 152-161. [in Ukrainian]

7. Termena B. K. London planetree in Ukraine. Introduktsiya ta aklimatyzatsiya roslyn v Ukraini. 1971. Vyp. 5. S. 43-49. [in Russian]

8. Fedorovskiy V. D., Mazur A. E. Woody plants of the Krivoy Rog Botanical Garden. Dnepropetrovsk : Progress, 2007. 256 s. [in Russian]

9. Shkarpet O. D. Introduction of planetrees in the Crimea. Byulleten gosudarstvennogo Nikitskogo botanicheskogo sada. 1987. Vyp. 63. S. 18-21. [in Ukrainian]

10. Shchepotev F. L., Pavlenko F. A. Breeding fast growing tree species. M. : Lesnaya promyshlennost, 1975. 232 s. [in Russian]

${ }^{I}$ A. O. Zahorulko, ${ }^{2,3}$ I. I. Korshykov

${ }^{1}$ Kherson State University, Ukraine

${ }^{2}$ Kryvyi Rih Botanical Garden, NAS of Ukraine, Ukraine

${ }^{3}$ Donetsk Botanical Garden, NAS of Ukraine, Ukraine

\section{LONDON PLANETREE (PLATANUS ACERIFOLIA WILLD.) UNDER CONDITIONS OF STEPPE TOWNS}

For steppe cities, it is important to replenish the range with durable decorative species that grow quickly and form a three-dimensional crown. Such plants due to the shading of large areas create more comfortable living conditions for people in steppe cities. These species include London planetree (Platanus acerifolia Willd.), which sporadically began to be planted in some cities in the postwar period. The viability of $P$. acerifolia in the steppe is different. Since the biological peculiarities of this introduced species have been studied in various socio-economic problems in cities, we conducted a comparative analysis of the vital state and biometric parameters of $P$. acerifolia in the plantations of two cities of the steppe zone of Ukraine.

We found out that $P$. acerifolia is widely used in landscaping of Kherson, while in Kryvyi Rih it is rare. In Kherson, the species is distributed near administrative buildings, schools, hospitals; it grows in parks, squares and yards of high-rise buildings, and in Kryvyi Rih only in one subdistrict and in the arboretum of the Kryvyi Rih Botanical Garden. The trees in Kherson are aged 38-60. The vital state is estimated as high and close to high - 77.8-96.3\%. Older trees are 18.4-21.5 m of height and a maximum trunk diameter is $80.1-99.4 \mathrm{~cm}$. Plants of all plantations in Kherson have dry branches, with a rate of 6.3-28.7\%. In Kryvyi Rih, 28-42-year-old trees grow. In different plantations of $P$. acerifolia, the number of dry branches varies in the range of $0.3-44.5 \%$, and the vital state - from 55.5 to $100 \%$ depending on the place of growth. The height of $P$. acerifolia trees is $6.2-20.3 \mathrm{~m}$, and the trunk diameter is $12.2-68.7 \mathrm{~cm}$. The study has proved that the differences in vital state and morphometric parameters of trees in the plantations of these cities depend on the age of trees, their planting density, lighting and other growing conditions. Trees in Kryvyi Rih are more significantly damaged by cold winds than in Kherson.

The life form of $P$. acerifolia in the plantations of Kherson and Kryvyi Rih is almost everywhere a single-stemmed tree. This species is beginning to naturalize in the conditions of Kherson. Several plants of self-seeding origin were found during the research studies. Restoration of plants with young sprouts produced by stumps after cutting the plant trunks in Kherson was also noticed. The leaf apparatus of plants during the growing season is practically not damaged by diseases and pests and no slimy stains are formed on the leaves.

We determined that $P$. acerifolia is a promising species for wider use in landscaping of the cities of the Black Sea coast and settlements of the Right-Bank Steppe, but in the latter case requires successful selection of exhibition sites for successful growth. These, first of all, should be cozy places protected from the effects of cold winds in winter and dry winds in spring and summer.

Key words: Platanus acerifolia Willd., morphometric parameters, vital state, Kherson, Kryvyi Rih.

Надійшла 04.11.2020. 